This is an open access article

under the CC-BY-SA license

\title{
Identitas Lokal Masyarakat Etnik Panaragan
}

Yusuf Adam Hilman, Ekapti Wahjuni Dwijayanti, Khoirurrosyidin

adamhilman@umpo.ac.id, ekapti_wahjuni@umpo.ac.id, rosyidin.kh@gmail.com

Fakultas Ilmu Sosial dan Ilmu Politik, Universitas Muhammadiyah Ponorogo, Jawa Timur

\begin{abstract}
Abstrak
Masyarakat Ponorogo diyakini memiliki kemampuan mistis atau ghaib. Persepsi masyarakat memahami karakter Ponorogo seperti Warok yang cenderung berbahasa asertif, terbuka, dan kasar. Lakon kesenian Reyog yang dikenal sebagai Warok merupakan tokoh antagonis. Stigma negatif muncul berdasarkan kurangnya pemahaman masyarakat terhadap sejarah kebudayaan Paragan. Identitas Panaragan sesungguhnya memiliki nilai-nilai budaya luhur. Tulisan ini bertujuan untuk mengidentifikasi identitas etnik Panaragan, secara lebih mendalam berdasarkan persebarannya, wujud kesenian, pola interaksi, bahasa, serta praktik visualisasi identitas serta karakteristik di ruang publik. Metode kualitatif deskriptif diaplikasikan melalui pengumpulan data dari hasil studi literatur dan observasi. Analisis data melalui teknik triangulasi bersumber dari telaah pustaka terhadap jurnal, buku, serta dokumentasi yang diperoleh di lapangan. Identitas lokal etnik Panaragan dipengaruhi oleh, 1) kesenian Reyog yang mempopulerkan sosok Warok sebagai orang sakti, kuat dan berpengaruh. Dalam masyarakat Jawa, istilah Warok identik dengan Wewarah yang dipahami sebagai sosok yang mampu memberi petunjuk atau pengajaran kepada orang lain tentang hidup yang baik. Dalam pemahaman Islam, wara' merupakan status sosial bagi seorang yang menempuh jalan sufi. Sayangnya, ketika era kolonialisme, sosok Warok dikonstruksi menjadi imej yang digunakan untuk menakut-nakuti dan pengaman bagi daerah; 2) Dialek Panaragan yang khas 'Warokan' dituturkan secara lugas dan asertif dengan intonasi tinggi merupakan pengaruh dari diksi dan gaya bahasa pertunjukan Reyog. Di sisi lain, konstruksi budaya baik melalui simbol seni rupa dan seni pertunjukan budaya Panaragan membentuk karakter masyarakat asli Ponorogo yang memiliki karakter gigih, mandiri, pemberani, dan gemar merantau.
\end{abstract}

Kata kunci: Dialek, Etnik Panaragan, Identitas Lokal, Reyog, Warok.

\begin{abstract}
People of Ponorogo is believed to have mystical or supernatural abilities. Public perception understands the character of Ponorogonese as Warok who tends to speak assertive, open, and rude. Warok is the one of antagonist theatrical drama player of Reyog. Negative stigma arises based on the lack of public understanding of the history of Paragan culture. Panaragan's identity actually has noble cultural values. This paper aims to identify Panaragan ethnic identity, in greater depth based on its distribution of settlement, art performance, patterns of interaction, language, and the practice of visualizing identity and characteristics in public spaces. The descriptive qualitative method was applied through data collection from the results of literature studies and observations. Data analysis through triangulation techniques was sourced from literature review of journals, books, and documentation obtained in the field. Panaragan ethnic local identity is influenced by, 1) Reyog performance art that popularized the figure of Warok as a powerful and influential person. In Javanese society, the term Warok is identical to Wewarah, which is understood as someone who is able to teach others about a good life. In the understanding of Islam, wara' is a social status for those who take the Sufi path. Unfortunately, during the era of colonialism, the figure of Warok was constructed into an image that was used to frightening people and maintain the ruler authority; 2) The Panaragan dialect 'Warokan' is spoken in a straightforward and assertive manner with high intonation which is the influence of art performance Reyog's diction and language style. On the other hand, cultural construction through visual arts symbols and Panaragan cultural performances represent the character of the Ponorogo indigenous people who are persistent, independent, brave, and adventurous.
\end{abstract}

Keywords: Dialect, Ethnic Panaragan, Local identity, Reyog, Warok.

\footnotetext{
* Corresponding author: Yusuf Adam Hilman. Fakultas Ilmu Sosial dan Ilmu Politik, Universitas Muhammadiyah Ponorogo. Jalan Budi Utomo No 10 Ronowijayan, Kec. Siman, Kabupaten Ponorogo, Jawa Timur 63471
} 
This is an open access article

under the CC-BY-SA license

\section{Pendahuluan}

Tulisan ini menaruh perhatian pada identitas masyarakat yang dikenal sebagai etnik Panaragan yang terletak di wilayah Kabupaten Ponorogo, Provinsi Jawa Timur. Pencirian etnik Panaragan dalam beberapa referensi memperlihatkan komunitas tersebut memiliki karakteristik unik dan berbeda, karena walaupun secara demografis berada di Provinsi Jawa Timur namun sangat dekat dengan kultur kebudayaan Jawa yang ada di Surakarta ataupun Yogyakarta, yang sering disebut sebagai kebudayaan Mataraman. Secara administrasif Jawa Timur terdiri dari 38 Kabupaten/Kota dengan keragaman budaya. Terdapat komunitas masyarakat dengan identitas dan karakteristik tertentu yang disebut sebagai tlatah kebudayaan. Tlatah kebudayaan yang ada di wilayah Jawa Timur antara lain: Jawa Mataraman, Kebudayan Arek, Osing, Madura, dan Pandhulungan. Secara spesifik Tlatah tersebut dapat di lihat dalam beberapa komunitas kecil masyarakat, menjadi beberapa, yakni: Jawa Panaragan, Samin/Sedulur Sikep, Tengger, Madura Kepulauan, Madura Bawean, dan Madura Kangean (Nurmayanti, Wulandari, \& Nugroho, 2017)

Ponorogo is the modern Indonesian spelling of the Javanese - 'Panaraga', the name by which it was previously known. This name, said to be derived from the Sanskrit words - 'Pramana Raga' is attributed to Bathara Katong who became the areas first Islamic ruler in the late fifteenth century. Previous to this, dating back to the time of Airlangga in the eleventh century, the area was known by the name of Wengker. During the time of the Majapahit empire, from the fourteenth century, both the name of Wengker and Pamotan seem to have been interchangeable (Campbell, 2009).

Masyarakat Ponorogo yang merupakan etnik Panaragan mendapat beberapa stigma negatif dari masyarakat di luar komunitas. Pertama, dari cara berbahasa yang cenderung lugas, terbuka, dan tanpa basa-basi, etnik Panaragan terkesan lebih kasar dibanding masyarakat Jawa pada umumnya.Masyarakat Ponorogo sama dengan masyarakat di negara Indonesia secara umum menggunakan dwi bahasa, yakni bahasa Indonesia sebagai bahasa resmi nasional yang digunakan dalam aktifitas, seperti dalam proses belajar mengajar atau dunia pendidikan, kehidupan ekonomi, dan aktifitas pemerintahan. Penggunaan bahasa Jawa juga dipakai dalam aktifitas keseharian di rumah. Dalam penggunaan bahasa Jawa yang memiliki banyak dialeg, masyarakat Ponorogo menggunakan bahasa Jawa yang bisa dikatakan standar. Penggunaan bahasa Jawa di wilayah pedesaan Provinsi Jawa Timur memiliki karakteristik yang agak kasar dan berterusterang atau berkesan 'blak-blakan', berbeda dengan model penggunaan bahasa Jawa yang ada di wilayah Jawa Tengah dengan model lebih basa-basi, berbelit-belit serta berkarakter lebih halus (Campbell, 2009).

Kedua, stigma negatif masyarakat terhadap komunitas masyarakat Ponorogo dipengaruhi oleh eksistensi tokoh kesenian Reyog yang dikenal dengan Warok. Beberapa literatur menggambarkan Warok sebagai tokoh antagonis yang gemar minum-minuman keras, berjudi, 'bermain wanita', foya-foya hingga pelaku homoseksualitas. Stigma ini begitu lekatnya dalam diri Warok, hampir tidak bisa dibantah jika beberapa ciri perilaku tersebut menjadi bagian dari kehidupan warok Ponorogo terutama pada era masa lalu (Khoirurrosyidin, 2014).

Ketiga, keberadaan warga Ponorogo yang merantau atau diaspora dianggap memiliki ilmu gaib oleh warga setempat. Masyarakat percaya bahwa orang yang berasal dari Ponorogo dapat menyedot kekayaan tetangganya (Suharto, 2003). Hal ini bersumber dari literatur sejarah di mana Warok - yang terkenal dari kesenian Reyog Ponorogo- berasal dari kata Wengker. Wengker adalah 
nama sebelum Islamisasi yang merujuk pada Bathara Katong di Ponorogo. Wengker adalah kerata basa 'wewengkon kang angker', yaitu suatu wilayah yang menakutkan. Sebutan ini merujuk kepada kondisi sosiologis masyarakatnya yang terkenal tidak ramah dan kerap melakukan ritual-ritual mistik (Nurdianto, 2018).

\section{Makna Identitas Lokal dan Perkembangan Budaya di Ponorogo}

Tulisan ini menaruh perhatian pada identitas lokal masyarakat yang menjadi basis kebudayaan daerah. Kebudayaan daerah merupakan bagian dari nilai-nilai kearifan lokal yang patut dilestarikan demi memperkuat keberagaman dalam wawasan kebangsaan. Berdasarkan para Sosiolog dan Antropolog, budaya merujuk pada konsep kehidupan masyarakat yang berupa simbol-simbol/pertanda, seperti penggunaan kesenian, pakaian adat, ritual, dan norma-norma. Hal ini tersebut melekat pada identitas kesukuan sebuah komunitas masyarakat (Fauzia, 2009). Adapun karakteristik budaya masyarakat direduksi ke dalam bahasa, kepercayaan, nilai norma, bahkan perilaku komunitas dengan berbentuk obyek material yang dapat disentuh, dilihat, dan dirasakan eksistensinya. Budaya secara sederhana diterjemahkan menjadi kebudayaan yang bersifat fisik dan non fisik dalam sebuah kelompok manusia (Matondang, Lubis, \& Suharyanto, 2018).

Kemunculan kearifan lokal dapat disebabkan oleh kepandaian masyarakat dalam sebuah komunitas yang berproses melalui pengalaman yang dialami. Kearifan lokal merupakan hasil dari pengalaman individu ataupun kelompok dalam kehidupan yang dijadikan sebagai tata nilai yang dipercayai dan tertanam kuat didalam sebuah komunitas (Fajarini, 2014). Perkembangan nilai kearifan lokal dalam sebuah komunitas masyarakat secara alamiah tanpa disadari kemudian mendapat sentuhan teknologi memunculkan bentuk baru yang telah beradaptasi. Seiring dengan perkembangan waktu dan zaman, terkadang masyarakat hanya memahami bahwa kearifan lokal sebagai bentuk keterkaitan dirinya atau komunitasnya dengan kehidupan leluhur serta nenek moyangnya, sehingga mempersatukan kehidupan antar individu yang ada dalam komunitas tersebut (Pattinama, 2009).

Eksistensi dari kearifan lokal berpengaruh terhadap kepribadian masyarakat yang menjadi pembentuk identitas serta kebanggaan dalam sebuah komunitas masyarakat. Nilai yang muncul kemudian diyakini kebenarannya oleh mereka sebagai hasil dari pemikiran filosofis dari sebuah komunitas tersebut (Kanzunnudin, 2017). Identitas dan karakteristik sebuah komunitas masyarakat bisa dilihat dari penggunaan bahasa daerah, tradisi yang diwariskan, serta dari budaya yang terbentuk melalui bentuk pergaulan dan juga interaksi yang terjadi antar anggota masyarakat dalam sebuah komunitas (Humaeni, 2015).

Identitas yang terbentuk dalam sebuah komunitas masyarakat merupakan kebanggaan yang melekat pada diri manusia, dimana identitas tersebut akan menentukan keanggotaannya dalam sebuah komunitas. Identitas budaya tertentu dapat berasal dari karakteristik atau kekhasan yang diyakini oleh mereka, pada agama, bahasa, dan adat istiadat yang terkandung dalam budaya yang bersangkutan (Brata, 2016).

Kabupaten Ponorogo selain memiliki kesenian daerah, seperti Reyog, ada beberapa kesenian lain, yang hadir dan berkembang dalam komunitas masyarakat tersebut, diantaranya: Gajah-Gajahan, Gong Gumbeng, dan Jaranan Thik. Keberadaan Gajah-Gajahan, Gong 
This is an open access article

under the CC-BY-SA license

Gumbeng, dan Jaranan Thik, Shalawat Gembrungan memang belum sepopuler Reyog (Dwijayanto \& Rohmatulloh, 2018). Pada tahun 1992 juga muncul kesenian Tari Keling yang telah mendapat pengakuan dari Pemerintah Daerah sebagai satu-satunya di Ponorogo bahkan diseluruh dunia. Selain itu, Pemerintah Daerah mempromosikan kesenian tari Keling baik di daerah maupun di luar kota melalui pentas budaya atau parade (Jayanti \& Herawati, 2018)

Tari Gajah-gajahan dalam sejarah Indonesia adalah kesenian yang hadir sebagai wujud kontra masyarakat terhadap eksistensi Reyog dan juga dilatarbelakangi oleh persaingan politik di Kabupaten Ponorogo. Reyog yang merupakan kesenian asli daerah Ponorogo dicurigai menjadi basis partai Komunis saat itu (Ruswananta \& Trilaksana, 2019). Para santri kemudian menciptakan kesenian tari yang harapannya bisa menyaingi kesenian Tari Reyog yang sudah melekat pada masyarakat Ponorogo. Kesenian Gajah-gajahan memiliki Syair Utawen yang dinyanyikan ketika bulan ramadhan dan biasa dilantunkan di Pesantren Gerbang Tinatar, yang merupakan pondok pesantren yang di dirikan oleh Kyai Ageng Muhammad Bashari. Ia salah seorang ulama penyebar Islam di daerah Ponorogo, lirik syair berbahasa Jawa dan Arab, syair tersebut berisikan tentang kisah Nabi Muhammad dan juga berkaitan dengan Ke Esaan Allah Subhanahuatala (Kusuma \& Suryadi, 2019).

Sejarah panjang kesenian Reyog berhasil melewati pasang-surut perjalanan waktu mulai dari: kerajaan Wengker, kerajaan Bantarangin, zaman Bathara Katong, zaman penjajahan Belanda dan Jepang, zaman setelah kemerdekaan atau Orde Lama, zaman Orde Baru, dan zaman reformasi. Karakter seni-budaya kesenian reyog memiliki kesamaan karakter masyarakat Ponorogo, sehingga dengan kesamaan karakter tersebut masyarakat Ponorogo mampu memelihara, mempertahankan, dan melestarikannya. Nilai-nilai pada kesenian Reyog Ponorogo apabila dilihat dari konsep nilai Max Scheler, meliputi: a) nilai-nilai kerohanian yaitu memuat unsur-unsur batiniah seperti penjiwaan pada setiap pemain Reyog meliputi nilai dakwah, nilai kelestarian, nilai kepercayaan, dan nilai magis; b) nilai spiritual yaitu memuat hal-hal yang melahirkan gairah dan getaran jiwa meliputi: nilai budaya, nilai keindahan, nilai moral, nilai seni, nilai simbolik, dan nilai superioritas; c) nilai kehidupan yaitu memuat unsur-unsur lahiriah yang berkaitan dengan keperluan hidup keseharian meliputi nilai kepahlawanan, nilai keadilan, dan nilai kesejahteraan; d) nilai kesenangan yaitu memuat unsur-unsur pada pembiasan hidup positif meliputi: nilai hiburan, nilai kepuasan, nilai kompetitif, nilai material, dan nilai pertunjukan (Achmadi, 2014).

Beragam kesenian yang dimiliki oleh masyarakat Ponorogo memperlihatkan adanya proses reduksi nilai dalam berbagai bentuk kebudayaan di wilayah Kabupaten Ponorogo. Etnik Panaragan yang menjadi identitas lokal masyarakat Ponorogo sangat menarik untuk ditelusuri, dikaji, serta diamati secara ilmiah. Tulisan ini bertujuan untuk mendorong masyarakat memahami jati dirinya yang melekat pada konsep identitas etnik Panaragan. Dengan demikian, diskursus ini mencoba untuk melakukan analisis, terkait bagaimanakah identitas etnik Panaragan yang muncul dalam kehidupan masyarakat di wilayah Kabupaten Ponorogo.

Selama ini berbagai kajian tentang kebudayaan telah banyak dilakukan, khususnya yang terkait dengan etnik Panaragan, namun dari beberapa kajian tersebut belum memperlihatkan sebuah bentuk dan penanda dari eksistensi identitas komunitas tersebut. Padahal berbagai penyebutan sudah sering muncul dalam berbagai kegiatan keseharian masyarakat seperti kegiatan 
kebudayaan, kegiatan pemerintahan, kegiatan sosial, bahkan dalam kegiatan keagamaan. Padahal, identitas sebuah komunitas bagaimana pun merupakan pembeda sebuah kelompok satu dengan yang lainnya dan membentuk karakteristik masyarakat yang tidak begitu saja mampu digeneralisasikan secara umum (Khaliesh, 2014).

Sementara, etnik Panaragan memiliki ragam kebudayaan yang luhur, yang sangat banyak ragamnya. Kesan masyarakat di luar komunitas yang menganggap etnik Panaragan terlihat seperti apa yang digambarkan diyakini penulis sebagai relevansi sejarah yang membentuk konstruksi dari stigma negatif etnik Panaragan yang berasal dari luar komunitas tersebut. Penulis meyakini dalam kehidupan masyarakat akan tetap terjaga eksistensi kebudayaannya jika mampu menjaga identitas dan karakteristiknya. Dengan demikian tulisan ini bertujuan untuk mengidentifikasi identitas etnik Panaragan, secara lebih mendalam berdasarkan persebarannya, wujud kesenian, pola interaksi, bahasa, serta praktik visualisasi identitas serta karakteristik di ruang publik.

\section{Metode}

Penulis menggunakan pendekatan kritis untuk menganalisis identitas masyarakat Panaragan. Teknik analisis menekankan pada pengungkapan secara mendalam terhadap apa saja yang ada di balik ilusi, atau yang menjadi kebenaran semu, dengan tujuan untuk membentuk kesadaran sosial masyarakat (Hidayat, 2002). Paradigma kritis memperlihatkan bagaimana penafsiran peneliti pada obyek yang akan dianalisis, diperlukan proses dialogis, dimana dialog secara kritis dibangun untuk melihat secara mendalam sebuah kenyataan sosial, sehingga memunculkan analisis yang menyeluruh di semua level (Diamastuti, 2011)

Teknik pengumpulan data bersumber dari telaah pustaka, observasi, dan dokumentasi. Peneliti menganalisis realitas Etnik Panaragan melalui konstruksi identitas lokal dan proses sejarah, ekonomi, sosial, politik dan budaya yang terjadi pada kehidupan masyarakat Ponorogo sebagai proses triangulasi data (Musianto, 2002).

Data yang dikumpulkan berupa literatur dari jurnal, buku, skripsi, tesis, yang berkaitan dengan kajian Etnik Panaragan, yang kemudian disajikan dan dianalisis sesuai dengan kaidah ilmiah, selanjutnya peneliti juga melakukan penggalian data berupa dokumentasi, seperti foto atau gambar yang menjadi bahan diskursus yang sesuai dengan kajian ini. Data yang telah dikumpul kemudian, di lakukan uji keabsahan data, melalui metode triangulasi sumber, sumber-sumber yang berhasil dikumpulkan, kemudian disusun secara berurutan, untuk memperlihatkan apakah data tersebut bertentangan atau saling mendukung.

\section{Hasil dan Pembahasan}

\section{Persebaran Masyarakat Tlatah Panaragan}

Secara kultural wilayah Jawa Timur dapat dibagi ke dalam 10 Wilayah besar kebudayaan, yaitu kebudayaan Jawa Mataraman, Jawa Panaragan, Arek, Samin (Sedulur Sikep), Tengger, Osing (Using), Pandalungan (sering juga disebut Mendalungan), Madura Pulau, Madura Bawean, dan Madura Kengean (Leni, 2012). Jawa Timur terbagi menjadi beberapa subkultur kebudayaan. Pertama, budaya Arek yang menjadi karakteristik masyarakat di Surabaya. Kedua, budaya yang mendekati subkultur Arek dengan ciri khasnya tersendiri. Subkultur tersebut banyak dijumpai di 
daerah-daerah yang menjadi penyangga kawasan Surabaya, yaitu Sidoarjo, Mojokerto, Jombang, Gresik, Tuban, dan Lamongan. Ketiga, budaya Mataraman yang merentang dan Ngawi, Kediri, Madiun, Nganjuk, Magetan, Trenggalek, Pacitan, Ponorogo, Tulungagung sampai Blitar. Keempat, budaya Pandalungan yang banyak dijumpai di pesisir pantai Jawa sebelah barat, khususnya, Pasuruan, Probolinggo, Situbondo, dan Jember. Sub-kultur Pandalungan semuanya dipengaruhi oleh Madura Islam. Kelima, subkultur Osing yang berada di Banyuwangi. Keenam, subkultur Samin yang agak mirip dengan Mataraman, namun mempunyai perspektif lain di luar Mataraman. Ketujuh, subkultur Tengger yang berada di Pegunungan Bromo dengan kultur yang agak khusus karena mendekati Majapahit. Selain itu, di Pulau Madura sendiri terdapat dua sub-kultur yang berbeda, yaitu Madura Kangcan dan Madura Bawean (Leni, 2012)

Secara geografis jika kita berbicara tentang Etnik Panaragan bisa ditunjukan di sebuah wilayah yang terdapat bagian barat Jawa Timur yakni Kabupaten Ponorogo, letaknya secara spesifik meliputi wilayah barat gunung Wilis dan sebelah timur dari gunung Lawu. Disana terdapat sebuah kerajaan yang bernama "Wengker" dan berkuasa cukup lama, istilah wengker diambil dari frasa "wengonan" tempat yang angker dan misterius. Menurut literatur sejarah kerajaan ini dipimpin oleh ratu Shima, yang kemudian melahirkan raja-raja yang ada di pulau Jawa. Dimasa berikutnya kerajan ini ditaklukan oleh Lembu Kanigoro, kemudian diganti nama menjadi Ponorogo. Proses pergantian nama kemudian, secara historis melahirkan percampuran budaya (alkulturasi), dalam proses tersebut terdapat 2 (dua) tradisi dan budaya besar yakni Hindu dan Islam, yang kemudian melahirkan kebudayaan Reyog. Raja yang berkuasa bernama Raden Bathara Katong mencoba melakukan kritik sosial atau sindiran (satire) terhadap Prabu Brawijaya V yang lemah karena intervensi dari permaisurinya. Model aklturasi budaya tersebut, kemudian dinamakan Ponorogoan atau Panaragan, dalam kesenian tersebut terdapat tokoh sosial kemasyarakatan yang kemudian disebut Warok. Identitas lokal masyarakat Panaragan merupakan perwujudan budaya yang memiliki kearifan lokal, diyakini keberadaanya dan diperjuangkan sebagai warisan leluhur. Budaya tersebut berbentuk fisik dan non fisik, yang telah melekat pada kehidupan masyarakatnya (Sugianto, 2016).

Pendapat para ahli mengutarakan adanya keterkaitan antara budaya yang terdapat pada Panaragan dan Mataraman dalam konteks bahasa, pakaian adat, tokoh lokal, peninggalan arkeologis, teknologi, serta sejarah. Kebudayaan etnik Jawa Panaragan mendorong munculnya beberapa kesenian khas daerah Ponorogo antara lain Reyog, Keling, Unto-Untoan, GajahGajahan, Jaranan thek. Berbagai kesenian tersebut tumbuh sumber di Ponorogo (Sugianto, 2016).

Komunitas masyarakat Panaragan mendiami sebelah barat gunung Wilis, spesifiknya adalah di Kabupaten Ponorogo. Etnik ini memiliki kesenian khas yakni Reyog, keberadaan nya mencerminkan simbol kebudayaan, hal tersebut bisa dilihat dari aspek kearifan lokal, pola piker, pandangan hidup, serta prilaku kesehariannya yang membentuk pola-pola khusus yang memiliki nilai yang dianut oleh komunitas masyarakat tersebut. pendekatan etnolinguistik menjadi hal yang penting untuk mengetahui lebih mendalam terkait kehidupan keberagaman, sosial, ekonomi dari tlatah kebudayaan masyarakat Etnik Panaragan (Sugianto, 2016).

Kajian budaya secara prinsip memiliki dua dimensi, yaitu budaya fisik dan budaya non fisik, hal tersebut meliputi: agama, kesenian, tradisi, kepercayaan dan lain sebagainya. sebagai hasil cipta, 
rasa, dan karsa kebudayaan atau budaya kemudian mempengaruhi pola hidup suatu kelompok masyarakat. budaya yang ada dipercaya dan dilaksanakan oleh sebuah kelompok masyarakat secara turun-temurun, didalamnya terdapat norma dan nilai yang telah disepakati bersama. Kepercayaan masyarakat dalam konsep kebudayaan kemudian disosialisasikan dan tersebar dalam batas wilayah, yang didiami oleh kelompok tersebut, walaupun tidak menutup kemungkinan terdapat kesamaan dengan daerah lain yang berdekatan letaknya. Kesamaan budaya pastinya dilatarbelakangi oleh kesamaan historis maupun adanya interaksi yang dilakukan di masa lampau. Budaya dalam masyarakat Etnik Panaragan merupakan hasil akulturasi antara budaya yang dipengaruhi oleh kepercayaan animisme dan dinamis, agama Hindu, dan Islam (Krismawati, 2018).

Nilai-nilai yang terkandung dalam budaya fisik dan non fisik di sebagai kearifan lokal menjadi pandangan hidup masyarakatnya. Kebudayaan dalam kesenian Reyog baik, Reyog pentas maupun kesenian Reyog Obyogan, memperlihatkan kearifan lokal yang dimiliki oleh masyarakat Etnik Panaragan. Kesenian Reyog pentas telah mengalami modifikasi sedemikian rupa dan disesuaikan dengan kondisi zaman, dalams etiap pementasan kesenian Reyog yang ditampilkan. Kesenian Reyog pentas ini pertunjukannya memakai pakem dan berdasar lakon Klana, sedangkan kesenian Reyog Obyogan yaitu kesenian yang hidup di pedesaan walaupun juga mengadakan pertunjukan, akan tetapi tidak memakai pakem. Pertunjukannya bisa memakai tempat di halamanhalaman rumah, perempatan atau pertigaan jalan desa, di pelataran pekuburan (Achmadi, 2013)

Keberadaan etnik Panaragan lekat sekali dengan nilai-nilai, lokal, bahkan ada beberapa hal yang selalu dikaitkan dengan tlatah kebudayaan yaitu kesenian Reyog Ponorogo. Tokoh Warok sebagai salah satu orang kuat yang sakti dan dihormati dalam komunitas tersebut, bagaimana mereka berinteraksi dengan penggunaan bahasa Jawa dialek Panaragan yang masih melekat pada kehidupan masyarakat. Hal inilah yang membuat etnik Panaragan merupakan etnik yang memiliki karakter, mandiri, pemberani, dan lebih suka merantau. Etnik Panaragan dianggap berbeda dari masyarakat Jawa pada umumnya atau yang dikategorikan sebagai Etnik Mataraman (Sugianto, 2015).

\section{Kesenian Reyog}

Kesenian Reyog Ponorogo memiliki sejarah panjang, melegenda, dan menjadi kebanggaan masyarakat Ponorogo. Sejarah panjang kesenian Reyog dan perkembangannya dimulai dari kerajaan Wengker hingga saat ini. Kesenian Reyog dikatakan melegenda, karena kesenian ini sangat erat kaitannya dengan tokoh legendaris Bathara Katong sebagai 'Bapak-e Wong Ponorogo'. Sejarah panjang kesenian Reyog berhasil melewati pasang-surut perjalanan waktu mulai kerajaan Wengker, kerajaan Bantarangin, zaman Bathara Katong, zaman penjajahan Belanda dan Jepang, zaman setelah kemerdekaan atau Orde Lama, zaman Orde Baru, dan zaman reformasi. Karakter kesenian Reyog memiliki kesamaan dengan karakteristik masyarakat Ponorogo, yang menjadikan masyarakat Ponorogo mampu memelihara, mempertahankan, dan juga melestarikannya (Achmadi, 2014).

Reyog merupakan salah satu cabang seni tradisional yang masuk kategori teater ritual yang merupakan bagian dari seni pentas yang berakar dari kebudayaan kuno ataupun kepercayaan suatu bangsa. Seni pentas semacam itu menjadi semacam memori yang masih bertahan 
This is an open access article

under the CC-BY-SA license

menyimpan suatu kenangan saat kehidupan dan kesibukan manusia belum terpisahkan dengan doa-doa dan ritual kepercayaannya. Di masa itu, manusia hidup selaras dengan alam dan menganggap dirinya sebagai bagian tak terpisahkan dari alam. Oleh karena itu, teater ritual yang berkembang di zaman itu mengemas pelbagai konsep yang terlihat berbeda itu menjadi sebuah tontonan seni (Hasanah, 2012).

Reyog Ponorogo jika ditelisik secara detail, terdapat beragam versi berdasarkan proses kemunculannya. Pertama, berdasarkan legenda panji yang terkenal. Kedua, Reyog Panorogo sebagai pertunjukan satire. Namun secara umum ada 4 (empat) model versi yang dipercaya oleh masyarakat; berdasarkan legenda panji 1) Versi Klono - Sanggolangit, bercerita tentang perang antara dua kerajaan yakni Daha (Kediri) dan kerajaan Bantarangin Panorogo, 2). Versi Wijaya Kilisuci. Bercerita tentang perang antara kerajaan Kahuripan (Airlangga) dan kerajaan Wengker (Wijaya), 3). Versi Asmarabangun - Rahwanaraja, berkisah seputar cerita Panji yang dapat menggambarkan tentang prototipe Reyog Ponorogo, 4). Versi Jathasura - KilisuciBujanggalelana dan versi Kelana Candrakirana, berkisah tentang ketiga cerita tersebut, dengan beberapa perbedaan. Tema yang kedua sebagai pertunjukan satire mempunyai latar belakang sejarah (Wahyudiyanto, 2013).

Secara runut dalam sebuah pertunjukan kesenian Reyog biasanya diawali dengan Tarian Topeng Ganong yang melakukan gerakan menggoda 'Dhadhak Merak', dengan gerakan geculan, setelah itu dilanjutkan dengan gerakan permusuhan antara keduanya, hal itu membuat pertunjukan ini semakin menarik dan memikat penonton. Pemegang peran yang lain dalam kesenian Reyog, diantaranya Warok, Jathil, Klana Topeng sebagai penari depan yang berbaris menjadi 'cucuk lampab' untuk mengawali barisan dengan bentuk gerak yang sederhana, seperti formasi sebuah pasukan perang (Mayono, 2007).

Biasanya seni pertunjukan Reyog disajikan dalam bentuk sendratari, yang menggambarkan tarian dramatik, tidak memiliki dialog, karena alur cerita tersebut dapat dilihat dari gerakan yang telah mewakili tema dan isi pertunjukan. Dalam pertunjukan Reyog ada beberapa tokoh yang menjadi lakon utama atau peran pembantu dalam setiap pementasan, tokoh-tokoh tersebut diantaranya adalah: Warok, Jathilan, Pujangga Anom, Klana Sewandono, dan Pembarong (Titimangsa \& Christanto, 2014).

\section{Warok}

Kesenian Reyog yang sudah termashur selalu diidentikan dengan masyarakat Ponorogo. Reyog sebagai kebudayaan luhur perlu dilestarikan. Salah satu tokoh yang sangat terkenal yaitu 'Warok' dapat dikenali dari ragam busana yang dikenakan, yang tidak hanya dipakai saat pementasan tetapi juga digunakan dalam kehidupan sehari-hari. Keberadaan Warok sebenarnya bukan bagian dari pertunjukan kesenian Reyog, karena sosok tersebut merupakan orang yang berpengaruh, yang sengaja diikutsertakan kedalam pertunjukan tersebut, dengan berbagai maksud dan tujuan tertentu.

Terminologi kata 'warok' bersinonim dengan 'weruk' yang memiliki arti 'besar sekali'. Frasa ini sehari-hari digunakan dalam masyarakat. Sebagai contoh, kalimat 'Bocahe wis warok' dapat diartikan dengan 'anaknya sudah besar'. Selain itu, kalimat 'Endi warokane?' diartikan sebagai 'mana yang besar, paling kuat, paling berani?'. Frasa diatas menjelaskan tentang maksud kata besar 
dalam artian memiliki keunggulan, keahlian, kehebatan. Konsep Islam Sufi mengenal istilah wara' yaitu menjauhkan diri dari segala sesuatu yang mengandung subhat (sesuatu yang belum diketahui hukumnya) yang menyebabkan seseorang terjerumus kepada sesuatu yang haram. Wara' adalah status sosial bagi seorang yang menempuh jalan sufi, status tersebut secara berurutan -taubah, wara', zubud, tawakal, sabar, dan kerelaan. Terminologi budaya Panaragan membagi Warok menjadi tiga, yaitu: Warok tua, Warokan, dan Warok muda. Warok adalah seorang pemimpin yang membawahi Warokan dan Warok muda, jadi Warokan dan Warok muda berada dibawah tingkat Warok, sedangkan Warokan terdiri dari pemuda jagoan yang pada grub kesenian Reyog, ia menjadi pemain Ganongan atau yang memaikan Barongan, sedangkan Warok adalah Pinituwa (pemiminnya). Seorang disebut Warok, jika ia sudah besar sekali wibawanya dan besar sekali kedudukannya dalam masyarakat. Ia disegani dan dihormati, gambaran dari seorang Warok, adalah diwujudkan dalam bentuk perawakan besar, berkumis, berjanggut panjang. Pada pipi dan dada tumbuh bulu-bulu hitam, menurut kepercayaan hitam mengandung makna keteguhan sedangkan lambang kesucian budi, ilmu, dan tingkah laku berupa koloran dan usus-usus yang berwarna putih, panjang dan terurai ujungnya. Dari sini akhirnya didapat pengertian bahwa manusia itu perlu sekali dikuatkan dengan kesucian budi, ilmu dan tingkah laku. Dahulu Warok, pada umumnya menjabat sebagai Demang, sedang dalam kesenian Reyog, ia sebagai pimpinan yang sekaligus menjadi pemain Barongan hal ini dengan harapan agar jiwa kstatria dan keteguhan hati secara tidak langsung menjiwai seluruh konco Reyog atau pelaku dalam kesenian Reyog (Taufiq, 2012).

Kesenian Reyog Ponorogo adalah bentuk prasasti seni yang terbilang otentik dan lengkap karena dalam pertunjukan didukung oleh seni musik, seni pertunjukan, dan seni tari. Dikisahkan dalam sebuah cerita bahwa warga Syailendrawangsa mereka memeluk agama Budha sekte Tantrayana. Menurut kepercayaan, kesempurnaan hidupnya dicapai dengan sakti. Cara untuk tetap sakti dengan melaksanakan pantangan dan menjauhi wanita. Dalam versi Budha, muncul istilah 'Warok' yang digambarkan sebagai 'Wiratamtama'. Ia diagungkan sebagai pengawal kerajaan. Kesaktiannya yang tinggi karena menjauhi wanita. Dalam beberapa literatur menyebutkan jika nalurinya lebih menyukai seorang laki-laki atau sejenis dengan ciri-ciri laki-laki yang berparas ayu atau manis. Pria pilihan Warok kemudian disebut dengan Gemblak (Kencanasari, 2009)

Terminologi Warok lainnya menjelaskan tentang kata 'Wewarah', yang diilustasikan dalam sebuah kalimat "wong kang sugih wewarah" atau diartikan sebagai seseorang menjadi Warok karena mampu memberi petunjuk atau pengajaran kepada orang lain tentang hidup yang baik. Dalam kehidupan sehari-hari peranan seorang Warok sangat sangat diagungkan dalam tlatah etnik Panaragan, dimana peranan tersebut harus ada prasyarat menjadi seorang Warok, adalah tubuh harus bersih karena akan diisi, harus dapat mengontol segala bentuk hawa nafsu, menahan lapar dan haus, juga tidak bersentuhan dengan perempuan (Khoirurrosyidin, 2014).

Sifat Warok menurut penuturan para ahli, a) Berwatak satria: jujur, dan suka memberi pertolongan, selalu berdarma bhakti kepada negara dan bangsa, b) Berwatak belas kasih kepada sesama, tetapi juga berwatak kejam kepada musuh, seperti pepatah jika lentur atau lemas dapat digunakan untuk tali, jika kaku dapat digunakan untuk pikulan, c) Banyak ilmu dan mempunyai kesaktian. Jika di waktu aman tenteram seperti tak ada gunanya. Tetapi jika terjebak mara bahaya dapat menyelesaikan perkara. Berdasarkan pepatah Jawa 'rawe-rawe rantas malang-malang putung', d) 
Menjadi suri tauladan dan pelindung masyarakat di desa itu dan sekitarnya. Kadang-kadang lurah saja kalah wibawa, e) Warok sejati, jika ditantang musuh tidak bernafsu, terlebih dahulu diberi peringatan. Jika sudah tidak dapat diperingatkan baru musuh itu dilawan semuanya mengajak bagaimana dituruti (Wiranata \& Nurcahyo, 2018).

Representasi tokoh Warok dalam konteks sosial adalah sebagai tokoh informal yang selalu dijadikan rujukan sikap, namun dalam perkembangannya di masa mendatang, posisinya akan digantikan oleh tokoh-tokoh LSM dan akademisi, yang dulunya memiliki peran sosial yang tinggi akan mengalami penurunan peran, dan akan kembali lagi seperti semula, hanya sebagai seniman. Masyarakat tidak banyak lagi yang memanfaatkan kemampuannya dalam mengakses informasi yang dibutuhkan. Masyarakat secara perorangan dengan bantuan teknologi informatika yang dikuasai sudah bisa mengakses secara langsung informasi yang dibutuhkan. Keberadaan tokohtokoh LSM dan akademisi dipandang lebih relevan oleh masyarakat, dengan ketrampilan dan pengetahuan yang lebih baik maka para tokoh LSM dan akademisi dipandang bisa memberikan solusi yang dibutuhkan masyarakat (Harsono \& Santoso, 2016).

\section{Dialek Panaragan}

Berdasarkan tata Bahasa dalam Bahasa Jawa, penggunaan kalimat dalam bertutur terdapat beberapa tingkatan yaitu Krama Inggil, Krama Madya, dan Jawa Ngoko. Bahasa Jawa Krama biasanya digunakan di wilayah Yogyakarta dan Jawa Tengah sebagai basis penyebaran bahasa Jawa. Digunakan untuk berbicara kepada orang-orang yang lebih tua usianya, status sosialnya lebih tinggi, dan di kalangan bangsawan atau kerajaan. Hal ini dicirikan dengan struktur bahasa yang tinggi maknanya, halus, dan sopan. Krama Madya pada umumnya digunakan kepada orang yang lebih tua atau orang asing, misalkan kepada guru, orang tua, atau orang asing yang baru ditemui. Hal ini dicirikan dengan struktur bahasa yang lebih formal. Sedangkan bahasa Jawa Ngoko pada umumnya digunakan untuk berbicara dengan orang yang sebaya, teman, atau yang lebih muda usianya. Struktur bahasa Jawa Ngoko terkesan lebih santai, familiar, dan asertif.

Kedekatan Kabupaten Ponorogo dengan kebudayaan Mataraman, menjadikan masyarakat di wilayah tersebut berada dipertengahan arus kebudayaan besar, mengingat secara administratif berada di Provinsi Jawa Timur namun secara geografis dan sejarah tidak bisa di pisahkan dengan kultur Mataraman, kondisi tersebut membentuk alkuturasi budaya yang unik, berbeda dengan daerah lain, khususnya dalam penggunaan bahasa Jawa, yang memunculkan logat serta Dialeg Panaragan. Dialeg Panaragan menggunakan bahasa Jawa Ngoko yang terkesan lugas, asertif, dan terbuka - tanpa basa-basi- berbeda dengan masyarakat Jawa Mataraman yang cenderung menggunakan bahasa Krama.

Perubahan bahasa dapat disebabkan oleh faktor intralinguistik -faktor di dalam bahasa sendiri dan faktor ekstralinguistik -faktor di luar bahasa yang meliputi faktor geografis, budaya, aktivitas ekonomi, politik, mobilitas sosial, kelas sosial, sifat masyarakat pendukung, persaingan prestis, migrasi, dan waktu kontak bahasa (Indrariani, 2013). Banyak ahli memaparkan bahwa Dialek Ponorogoan sangat identik dengan bahasa Warok, dengan intonasi tinggi, dan kental dengan bahasa Jawanya (Purwati, 2013). Kekhasannya para Warok ketika berbicara berupa diksi dan gaya bahasa menjadi dasar penelitian Achzarivien (Achzarivien, 2014). Warok diidentikan 
This is an open access article

under the CC-BY-SA license

sebagai gambaran komunitas masyarakat Ponorogo atau etnik Panaragan yang memiliki sifat, karakteristik, wujud, tingkah laku, hingga cara berbicara yang sama dengan penampilan pada pementasan pertunjukan Reyog. Namun dialek asli Panaragan tersebut keberadaannya semakin punah akibat pengaruh bahasa Jawa pada umumnya (Sugianto, 2016).

Etnik Panaragan juga memiliki ciri khas bahasa serta dialek khas Panaragan sebagai ciri komunikasi komunitas masyarakat Ponorogo dengan beberapa kosakata yang khas seperti 'jegeg' yang artinya berdiri tegak, 'ora dlomok' yang artinya spektakuler atau tidak lazim, 'dlondongane' yang bermakna anak atau keturunan, 'patak warak' artinya 'aran warok' - dilabeli jagoan dan dialek khas lain sebagainya. Keberadaan kesenian Reyog, tokoh Warok, dan dialek Panaragan merupakan bagian dari kebudayaan yang selama ini melekat dengan masyarakat Ponorogo. Hal ini menjadi ciri khas masyarakat walaupun telah membaur dengan masyarakat dari daerah lain.

\section{Visualisasi Identitas Lokal di Ruang Publik}

Beberapa karakteristik budaya diwujudkan dengan simbol-simbol tertentu sehingga menghadirkan realitas yang sengaja dikonstruksi untuk meneguhkan identitas lokal Panaragan. Beberapa fasilitas publik yang ada di Kabupaten Ponorogo menegaskan kembali kepada kita terhadap eksistensi etnik Panaragan (Nanda Cahyo Setiaji, 2018).

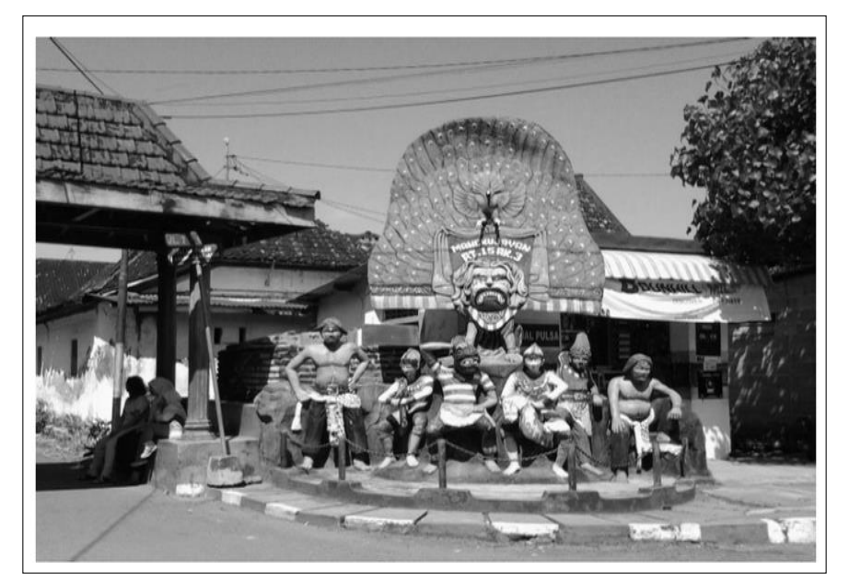

Gambar 1. Tokoh atau Pemeran dalam Kesenian Reyog

di Desa Caluk Kecamatan Slahung (Nugroho, 2015).

Pemerintah melalui salah satu Bupatinya, yakni Dr. H. Markom Singodimejo, kemudian mengabadikan budaya Reyog kedalam bentuk visual, dengan membuat patung yang bernuansa cerita Reyog Ponorogo. Hal tersebut dapat dilihat dari bangunan yang terdapat di perempatan jalan kota, pendopo Kabupaten, maupun di kawasan Alun-Alun Ponorogo. Kesenian Tradisional Reyog Ponorogo yang kaya akan sebuah nilai filosofi kehidupan orang Jawa kini hadir dalam bentuk patung, gapura, maupun unsur visual lainnya (Yurisma, 2019).

Gambar 2 memperlihatkan sosok Warok yang berdiri kokoh di salah satu ruas jalan di Kabupaten Ponorogo. Patung tersebut mengambarkan sosok 'sakti mandraguna'. Dalam beberapa literatur sejarah disebutkan jika sosok Warok sebenarnya tidak memiliki kaitannya dengan pertunjukan Reyog dalam alur cerita. Namun ketika era pemerintah kolonial, sosok Warok sengaja dikonstruksi untuk membentuk imej tertentu yang ditakuti masyarakat dan 
This is an open access article

under the CC-BY-SA license

dimasukkan ke dalam bagian dari penokohan Reyog. Warok hadir sebagai penggambaran pengaman dan juga orang kuat/perkasa yang ada di daerah. Pertunjukan Reyog pada masa tersebut menghadirkan dua jenis Warok, yakni Warok Muda dan Tua sebagai simbol karaktersitik masyarakat Ponorogo di masa penjajahan. Warok tua digambarkan sebagai sosok yang lebih bijaksana dan menguasai wilayah, sedangkan Warok muda menggambarkan warga Ponorogo yang identik dengan kasar, keras, terbuka dan egaliter.

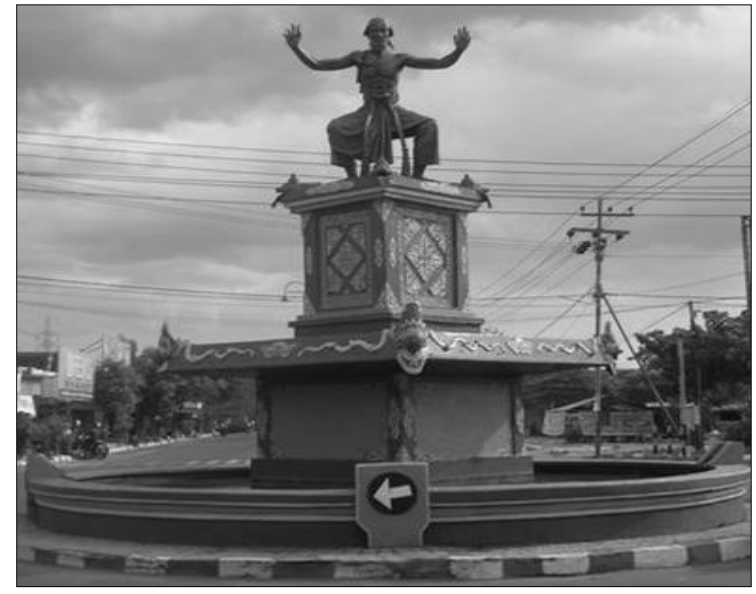

Gambar 2 Keberadaan Patung Warok di Perempatan Jalan

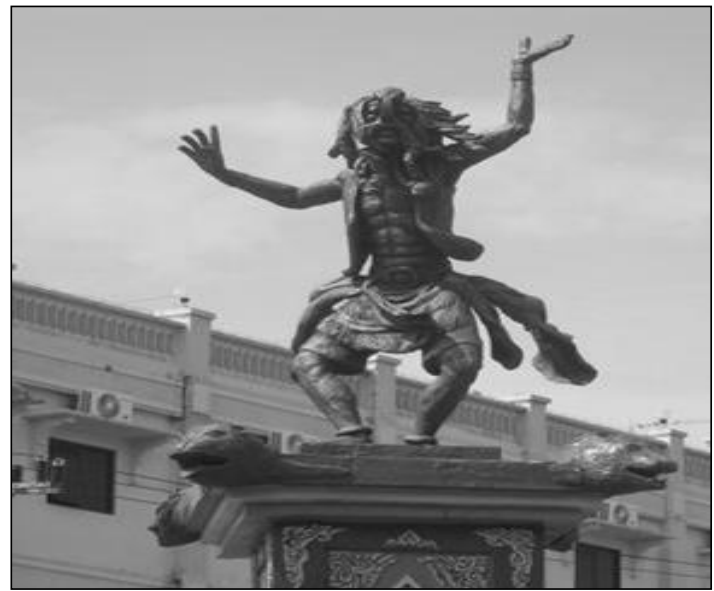

Gambar 3 Keberadaan Patung Pujanganom di Perempatan Jalan

Gambar 3 merupakan patung dari sosok Pujanggaanom yang dikenal sebagai pemuda yang lincah dan cekatan selain itu dia dikenal sebagai Patih yang bijaksana. Walaupun memiliki wajah yang buruk rupa, dalam memberikan pertimbangan atau usul kepada prabu Kelana Sewandono, dengan kecerdasannya ia selalu bisa menyelesaikan permasalahan sesuai dengan tepat dan efektif.

Gambar 4 adalah Taman Kelono Sewandono. Penamaan taman diambil dari nama Prabu Kelana Sewandono. Dikisahkan sebagai pangeran yang jatuh cinta dengan sorang putri bernama Songgo Langit, yang berasal dari kerajaan (Dhaha) Kadiri, beliau memiliki pusaka yang diberi nama Kiai Pecut Samandiman yang sangat sakti.
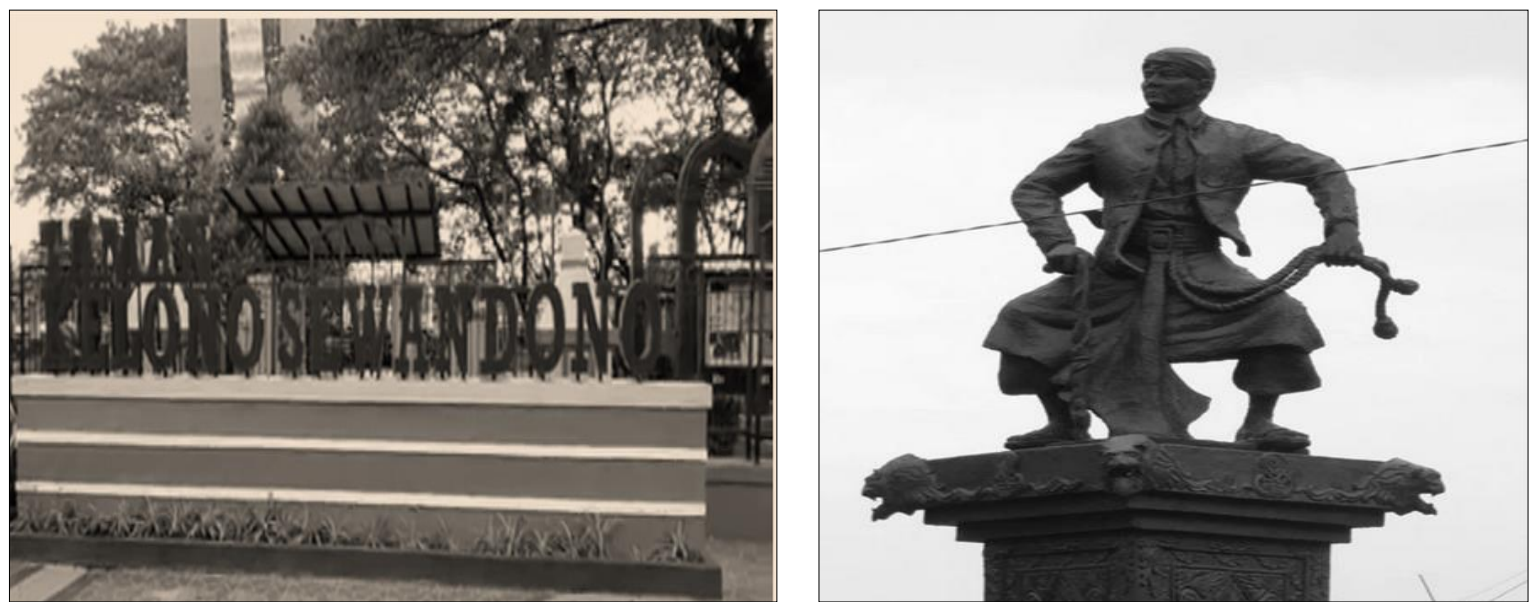
Gambar 4 Keberadaan Tokoh kesenian Reyog sebagai nama Taman Kota
Gambar 5. Keberadaan Patung Raden

Bathara Katong di perempatan jalan

Gambar 5 memperlihatkan patung Raden Bathara Katong. Ia merupakan salah satu tokoh yang berjasa dalam proses islamisasi wilayah Ponorogo, yang ketika itu dikuasai oleh Raja Wengker, keberadaan raden Bhatara Katong sangat berpengaruh terhadap kehidupan masyarakat di Kabupaten Ponorogo.

\section{Kesimpulan}

Identitas etnik Panaragan tercermin dalam beberapa aspek, diantaranya pertama, keberadaan kesenian Reyog Ponorog. Dalam pertunjukan tersebut terdapat tokoh Warok sebagai salah satu orang kuat dan pengaruh serta sakti yang dihormati dalam komunitas tersebut. Namun di era Kolonial, tokoh Warok sengaja dikonstruksi untuk membentuk imej antagonis sebagai sosok manusia yang berkuasa, kuat, sakti, dan ditakuti (memedi) sehingga menjadi pengaman bagi daerahnya masing-masing. Kedua, dialek Panaragan merupakan dialek yang digunakan dalam pertunjukan Reyog. Dialeg Panaragan memiliki intonasi tinggi dan asertif 'blak-blakan'. Bahasa Jawa dengan dialek tersebut melekat pada kehidupan masyarakat Panaragan merupakan turunan dari bahasa Jawa yang sudah tereduksi karena berbagai faktor sehingga membentuk dialeg Panaragan dengan karakteristik yang saat ini digunakan. Diksi dan gaya bahasa Panaragan yang relatif berbeda dengan masyarkat Jawa Matraman -yang cenderung halus dan 'basa-basi' - inilah yang banyak digunakan oleh orang Panaragan asli yang tinggal dan hidup dalam masyarakat Ponorogo. Sehingga banyak orang yang berada di luar komunitas tersebut yang belum memahami sejarah dan perkembangan budaya Panaragan, menilai orang Ponorogo itu memiliki kesan mistis dan kasar.

\section{Ucapan Terima Kasih}

Terima kasih kami sampaikan kepada Lembaga Penelitian dan Pengabdian (LPPM) Universitas Muhammadiyah Ponorogo yang telah memberikan dukungan dan bantuan terkait proses penelitian hingga bisa menghasilkan karya ilmiah berupa jurnal, selain itu kami haturkan terimakasih terhadap Program Studi Ilmu Pemerintahan, yang telah banyak membantu penyelesaian karya tulis ilmiah, semoga kerja tim ini bisa berlanjut dalam kesempatan lainnya.

\section{Daftar Rujukan}

Achmadi, A. (2014). Aksiologi Reyog Ponorogo Relevansinya dengan Pembangunan Karakter Bangsa. Teologia, 3 - 27.

Achmadi, A. (2013). Pasang Surut Dominasi Islam terhadap Kesenian Reog Ponorogo. Analisis (Studi Keislaman), 111-134.

Achzarivien. (2014). Lelewa Lan Pamilihe Tembung Basa Warok Ponorogo. Jurnal Online Baradha, 1-6.

Aji Akbar Titimangsa, J. C. (2013). Kajian Karakteristik, Persebaran dan Kebijakan Reog Ponorogo di Kabupaten Ponorogo Provinsi Jawa Timur. Bumi Indonesia , 1-10.

Brata, I. B. (2016). Kearifan Budaya Lokal Perekat Identitas Budaya Lokal. Bakti Saraswati , 9 - 16. 
Campbell, C. (2009). Health, Healing and the Quest for Wellbeing in Ponorogo Regency, East Java. English: University of Newcastle.

Diamastuti, E. (2011). Paradigma Ilmu Pengetahuan Sebuah Telaah Kritis. Akuntansi , 61 - 74.

Dwijayanto, A., \& Rohmatulloh, D. M. (2018). Ponorogo, the Little Java: Potret Kebudayaan Dan Keberagamaan Masyarakat Muslim Ponorogo Abad XX. Al-Adabiya: Jurnal Kebudayaan dan Keagamaan , 1 - 31.

Fajarini, U. (2014). Peran Kearifan Lokal dalam Pendidikan Karakter. Sosio Didaktita , 123 - 130.

Fauzia, I. Y. (2009). Menguak konsep kebersandingan fethullah gulen dan asimilasi budaya tariq ramadhan. Studi Keislaman Islamica, 3(2), 1-19. http://doi.org/http://islamica.uinsby.ac.id/index.php/islamica/article/view/45

Harsono, J., \& Santoso, S. (2016). Sosiologi Masyarakat Ponorogo. Ponorogo: UMPO Press.

Hasanah, U. (2012). Bathara Katong, Reyog Ponorogo, dan Penyebaran Islam di Jawa. IBDA': Jurnal Kajian Islam dan Budaya , 231-241.

Hidayat, D. N. (2002). Metode Penelitian dalam sebuah "Multi Paradigma Science. Mediator , 197 $-220$.

Humaeni, A. (2015). RRitual, Kepercayaan Lokal, dan Identitas Budaya Masyarakat Ciomas Banten. el - Harakah , 157 - 181.

Indrariani, E. A. (2013). Jejak Bahasa Jawa Samin Klopoduwur Blora (Sebuah Rekaman SInkronis). Sasindo: Jurnal Pendidikan Bahasa dan Sastra Indonesia , 1 - 12.

Jayant, D., \& Herawati, E. N. (2018). Eksistensi Tari Keling Guno Joyo di Dusun Mojo Desa Singgahan Kecamatan Pulung Kabupaten Ponorogo. Mangenjali (Pendidikan Seni Tari) , $1-10$.

Kanzunnudin, M. (2017). Menggali Nilai dan Fungsi Cerita Rakyat Sultan Hadirin dan Masjid Wali At - Taqwa Loram Kulon Kudus. KREDO : Jurnal Ilmiah Bahasa dan Sastra , 1 - 17.

Kencanasari, L. S. (2009). Warok dalam Sejarah Kesenian Reog Ponorogo (Perspektif Eksistensialisme). Jurnal Filsafat UGM , 179 - 198.

Khaliesh, H. (2014). Arsitektur Tradisional Tionghoa, Tinjauan Terhadap Identitas, Karakter Budaya dan Eksistensinya. Arsitektur : Langkau Betang, 86 - 99.

Khoirurrosyidin. (2014). Dinamika Peran Warok Dalam Politik di Ponorogo. Jurnal Humanity, 25-37.

Krismawati, N. U. (2018). Eksistensi Warok Dan Gemblak di tengah Masyarakat Muslim Ponorogo Tahun 1960-1980. Religio (Jurnal Studi Agama - agama), 116-138.

Kusuma, I., \& Suryadi, M. (2019). Reflection on the Meaning of Local Wisdom in Utawen Poetry at Gebang Tinatar Islamic Boarding School Tegalsari Ponorogo. Prosiding Seminar Nasional Linguistiks dan Sastra (SEMANTIKS) 2019 "Kajian Linguistik pada Karya Sastra" (pp. 593 - 605). Surakarta: Universitas Negeri Surakarta.

Leni, N. (2012). Demokrasi dan Budaya Politik Lokal di Jawa Timur menurut R. Zuhro dkk. Tapis (Teropong Aspirasi Politik Islam), 15-37.

Matondang, A., Lubis, Y. A., \& Suharyanto, A. (2018). Eksistensi Budaya Lokal Dalam Usaha Pembangunan Karater Siswa Smp Kota Padang Sidimpuan. Anthropos: Jurnal Antropologi Sosial dan Budaya , 103 - 116. 
Mayono. (2007). Reog Kemasan sebagai Aset Pariwisata Unggulan kabupaten Ponorogo (The Packes Reog as the high tourism of Ponorogo residence). Harmonia (Jurnal Pengetahuan Pemikiran Seni), 158-168.

Musianto, L. S. (2002). Perbedaan Pendekatan Kuantitatif dengan Pendekatan Kualitatif dalam Metode Penelitian. Manajemen dan Kewirausahaan , 123 - 136.

Nanda Cahyo Setiaji, M. H. (2018). Kajian Makna Simbolis Patung dan Monumen di Kabupaten Ponorogo Sebagai Sumber Pembelajaran Sejarah Lokal. Agastya: Jurnal Sejarah Dan Pembelajarannya , 59 - 74.

Nugroho, O. c. (2015). Interaksi simbolik dalam komunikasi budaya (Studi Analisis Fasilitas Publik Di Kabupaten Ponorogo). Aristo , 1 - 18.

Nurdianto, S. A. (2018). Ponorogo: Menggali Jati Diri Untuk Membangun Harmoni (Saifuddin. Jantra : Jurnal Sejarah dan Budaya , 1 - 9.

Nurmayanti, Y., Wulandari, L. D., \& Nugroho, A. M. (2017). Perubahan Ruang Berbasis Tradisi Rumah Jawa Panaragan di Desa Kaponan. Arsitektur : Langkau Betang , 31 - 43.

Pattinama, M. J. (2009). Pengentasan kemiskinan dengan kearifan lokal (Studi Kasus di Pulau Buru - Maluku dan Surade Jawa Barat). Makara : Sosial Humaniora , 1 - 12.

Priyatna, F. N., Kinseng, R. A., \& Satria, A. (2013). Akses dna Strategi aktor - aktor dalam Pemanfaatan sumber daya Waduk Juanda. Sosial Ekonomi Kelautan dan Perikanan , 1 9.

Purwati, E. (2013). (Studi Fenomenologi pada Masyarakat Kabupaten Ponorogo dalam Program Acara Dangdut Ponoragan di Radio Duta Nusantara). ARISTO , 91 - 107.

Ruswananta, S. P., \& Trilaksana, A. (2019). Kesenian Tari Gajah-gajahan Desa Gontor, Kecamatan Mlarak, Kabupaten Ponorogo. Avatara, Pendidikan Sejarah, 90 - 100.

Setiawan, E. (2016). Eksistensi Budaya Bahari Tradisi Petik Laut di Muncar Bnayuwangi. Universum , 229 - 237.

Sugianto, A. (2015). Kajian Etnolinguistik Terhadap Pribahasa Etnik Jawa Panaragan Sebuah Tinjauan Pragmatik Force. Seminar Nasional Prasasti II : Kajian Pragmatik dalam Berbagai Bidang" (pp. 51 - 55). Surakarta: Universitas Sebelas Maret.

Sugianto, A. (2016). Kebudayaan Masyarakat Jawa Etnik Panaragan. ARISTO, 45 - 52.

Suharto. (2003). Membangun Identitas Kebudayaan. Jember: Universitas Negeri Jember.

Taufiq, A. (2012). Bathara Katong, Reyog Ponorogo, dan Penyebaran Islam di Jawa. IBDA': Jurnal Kajian Islam dan Budaya , 231-241.

Titimangsa, A. A., \& Christanto, J. (2014). Kajian KarakteristikPersebaran dan Kebijakan Reog Ponorogo di Kabupaten Ponorogo. Bumi Indonesia , 1 - 10.

Wahyudiyanto. (2013). Reyog Ponorogo (Festival Reyog Nasional dalam Garap Bentuk dan Unsur Pertunjukan Reyog Ponorogo Serta Pesan yang Disampaikan). TEROB (Pengkajian dan Penciptaaan Seni), 12-33.

Wiranata, A. D., \& Nurcahyo, A. (2018). Peranan Gemblak Dalam Kehidupan Sosial Tokoh Warok Ponorogo. Agastya , 94 - 106.

Yurisma, D. Y. (2019). Kesenian Tradisi Reog Sebagai Pembentuk Citra Ponorogo. Visualita , 1 15. 
Copyright (C) 2020, Hilman, Dwijayanti \&

Khoirurrosyidin

This is an open access article under the CC-BY-SA license
Sospol: Jurnal Sosial Politik Vol 6 No 1 (2020), Hlm 98-113 